\title{
Moringa Nastar Increase Prolaktin As Support Of 1000 HPK Action With UNICEF Consept Approach
}

\author{
Ely Isnaeni , Erna Rahmawati \\ IIK Bhakti Wiyata Kediri, East Java, Indonesia \\ Corresponding author: ely.isnani@iik.ac.id
}

\begin{abstract}
Background: The percentage of exclusive breastfeeding decreases with increasing age groups of infants. The desire for exclusive breastfeeding is not supported by maximum milk production and the main reason is time constraints due to work so that it is not possible to provide breast milk directly or by way of pumping breast milk. The more nutrients that enter the mother, the more the hormone prolactin, and the more milk production. Moringa contains phytosterol compounds that work to increase and facilitate the production of breast milk (lactagogum effect).

Purpose: This study aimed to analyze the effect of Moringa Moringa to increase prolactin as a supporter of the 1000 The first day of life (HPK) movement with the UNICEF concept framework approach.

Methods: The research design uses pre-experiment research design with one group prepost tests design. Data were collected using purposive sampling with a total sample of 10 respondents. Data were analyzed using non-parametric data analysis techniques with the Mann Whitney test with $\alpha=0.05$, to see the effect of Nastar Moringa increasing Prolactin as a Supporter of the 1000 HPK Movement With Increased Unicef Conceptual Framework Result: The results of the study with the Mann Whitney test showed that the influence of Moringa nastar to increase prolactin levels was pvalue $=0.047$. Before given Moringa nastar, the mean was 37.06 and after given Moringa nastar increased to 56.51.

Conclusions: it is concluded that there is an influence of Nastar Moringa to increase prolactin as a supporter of the 1000 HPK movement. Based on the results of this study it is recommended that mothers consume Moringa nastar to increase levels of Prolactin
\end{abstract}

Keywords: Moringa Nastar, Prolactin, 1000 The first day of life

Received July, 29, 2019; Revised August 30, 2019; Accepted September 22, 2019

How to Cite: Isnaeni, E., \& Rahmawati, E. (2019). Moringa Nastar Increase Prolaktin As Support Of 1000 HPK Action With UNICEF Consept Approach. Journal Of Nursing Practice, 3(1), 109-113. https://doi.org/10.30994/jnp.v3i1.72 


\section{BACKGROUND}

In Indonesia, the percentage of exclusive breastfeeding decreases with increasing age groups of babies. In infants aged 5 months exclusively breastfeeding was only $15.3 \%$ in 2010 , but has increased by $36.2 \%$ in 2013, while infants 6 months exclusively breastfeeded by $30.2 \% 1$. The target of exclusive breastfeeding is $80 \%$ in 2015 . The results of the talk show "Philips Avent New Parents Class", 60\% of breastfeeding mothers stop breastfeeding earlier than they want. A survey from De Jager in 2013 said that 1 in 10 mothers stopped breastfeeding because they felt uncomfortable breastfeeding outside the home. Another survey also showed that more than $30 \%$ of breastfeeding mothers felt comfortable pumping breast milk in a closed room5.

This study uses 10 mothers at Gambiran City Hospital in Kediri taken through a purposive technique in which the researcher chooses to marry, work, have children, give breastfeeding although not exclusively and formula milk or other complementary foods when the baby is 0-6 months old. The results of the study show that the desire for exclusive breastfeeding is not supported by maximum milk production and the main reason is the limited time due to work so it is not possible to provide breast milk directly or by way of pumping breast milk and the lack of full support from families to provide exclusive breastfeeding. The hassle if you have to pump breast milk when working, the distance is too far between the place of work and home, must consume fibrous food.

The cause of nutritional problems in 1000 HPK (First Day of Life) for example infants do not get exclusive breastfeeding. Although the data above requires validation, what is clear is that the scope of exclusive breastfeeding is still far from the target that must be achieved in 2015, which is $80 \%$. According to UNICEF, "out of control" is an obstacle that causes ineffective promotion of exclusive breastfeeding. All efforts to improve nutrition outside this period have been proven unable to resolve the nutritional problems of the community thoroughly6.

Many factors affect the production of milk, milk production in the body depends on two hormones, namely prolactin and oxytocin. The more nutrients that enter the mother, the more the hormone prolactin, and the more milk production. Rahayu's research results stated that food factors significantly influence milk production in addition to psychological factors and baby sucking. Moringa plants are local food ingredients that have the potential to be developed in culinary nursing mothers, because they contain phytosterol compounds that function to increase and facilitate the production of breast milk (lactagogum effect) 2 . Theoretically, compounds that have the effect of lactagogum are sterols. Sterols are steroid compounds3. The results of Fuglie's research on malnourished communities in Senegal, Africa with Moringa leaf flour therapy showed significant results on the nutritional status of individuals4.

In addition to vitamin $\mathrm{C}$, the nutritional content will increase in quantity if Moringa leaves are consumed after drying and turned into powder (flour). Vitamin A in moringa leaf powder is equivalent to 10 times vitamin $\mathrm{A}$ in carrots, equivalent to 17 times calcium in milk, equivalent to 15 times calcium in bananas, equivalent to 9 times protein in yogurt and equivalent to 25 times iron in spinach7. Some of the above theories strengthen researchers to package Moringa leaf extract into a form of processed nastar bread so that it becomes an economical, practical, high nutritional value snack with the aim of analyzing the influence of Moringa nastar influence to increase prolactin as a supporter of the 1000 HPK movement with the UNICEF concept framework approach. 


\section{OBJECTIVE}

This study aimed to analyze the effect of Moringa nastar to increase prolactin as a supporter of the 1000 HPK movement with the UNICEF concept framework approach, which was carried out in nursing mothers.

\section{METHODS}

The research method uses a pre-experimental design with one group pre-post test design research design, aimed to determine the effect of Moringa nastar on increasing levels of prolactin in nursing mothers aged 0-6 months at Gambiran City Hospital in Kediri. The study population was breastfeeding mothers of infants aged 0-6 months, samples taken were some of the population that met the inclusion criteria, namely: 1) nursing mothers of infants aged 0-6 months, 2) working at the Gambiran City Hospital in Kediri. Purposive sampling technique with a sample size of 10 respondents. The research location used is the Gambiran City Hospital environment in Kediri because 65\% of the employees who work are women.

The participants were assured that their engagement was voluntary, and that anonymity, privacy, and confidentiality of the data were guaranteed. Furthermore, they were informed about the purpose and the method of the study before signing a written informed consent. The questionnaires were distributed to eligible participants at the Gambiran City Hospital, and respondents were asked to complete and return them in the same time.

\section{RESULTS}

The results of the study with the Mann Whitney test showed that the influence of Moringa nastar to increase prolactin levels was pvalue $=0.047$. Before given Moringa nastar, the mean was 37.06 and after given Moringa nastar increased to 56.51.

\section{DISCUSIONS}

The results of the study with the Mann Whitney test showed that the influence of Moringa nastar to increase prolactin levels was pvalue $=0.047$. Before given Moringa nastar, the mean was 37.06 and after given Moringa nastar increased to 56.51.

The initial puerperium amount of milk produced correlates with the amount of prolactin released during breastfeeding after birth, the main stimulus that maintains the secretion of prolactin is sucking, milk production will continue as long as the baby continues to suck breast milk. Every time a mother feeds her baby, nerve signals from the nipple to the hypothalamus will cause a surge of prolactin secretion of about 10 to 20 times which lasts about 1 hour, this prolactin works on the breast of the mother to maintain the mammalian glands to secrete milk into the alveoli for alveoli to subsequent lactation production (Guyton \& Hall, 2007).

This is supported by the results of research that prolactin levels differ in each preode, the results of research conducted on 16 breastfeeding mothers obtained different serum prolactin levels between groups of breastfeeding mothers 1 week postpartum, 4 weeks postpartum, 8 weeks postpartum, during the first menstruation after delivery and after the baby weaning. Prolactin levels of breastfeeding mothers 4 weeks post partum are higher compared with others (Glaiser, 2006).

Increased levels of the hormone prolactin because in nastar Moringa contains phytosterol chemical compounds namely poliferol and sterol, where these compounds play a role in increasing levels of prolactin, high levels of prolactin function to increase, accelerate, and 


\section{Journal Of Nursing Practice}

http://thejnp.org

ISSN: 2614-3488 (print); 2614-3496 (online)

Vol.3 No.1. October 2019. Page.109-113

facilitate the production of breast milk. Phytosterol and Steroid compounds contained in Moringa leaves have lactagogum effect power, in which the mechanism of lactagogum power of a compound can occur among others by: directly stimulating the protoplasmic activity of mammary gland secretory cells, stimulating the secretory nerve endings in the mammary gland so that secretion increased milk, or stimulates the prolactin hormone that acts on alveolar epithelial cells. Prolactin or luteotropin or LTH is a lactagonic and proliferative hormone against the mammary gland. The effect of prolactin in humans or mammals is stimulating lactation (PUspita, 2013). In addition, the function of lactogogum can also increase glucose metabolism for lactose sites, thus increasing milk production.

\section{CONCLUSIONS}

There is an effect of nastar Moringa to increase prolactin levels with a pvalue $=0.047$. Before given Moringa nastar, the mean was 37.06 and after given Moringa nastar increased to 56.51 .

\section{ACKOWLEDGMENT}

The author would like to thank the Institut Ilmu Kesehatan Bhakti Wiyata for providing financial assistance in publishing this research.

\section{REFERENCES}

Ministry of Health. Highlights of the 2013 Indonesian Riskesdas Results. 2014.

Titi Mutiara K. Test the Effect of Breastmilk Smoothing Powder for Moringa oleifera (Lamk) in White Wistar Strain Mice. Doctoral Dissertation Research Report. Poor; 2011

Nurmalasari MD. ISOLATION OF COMPOUNDS OF LEAVES OF LEAVES Sauropus androgynus (L.) Merr (Isolate of n-Hexane Faction: Ethyl Acetate = 80: 20). Undergraduate Thesis of Airlangga University. 2008. p. 4-6.

Fuglie LJ. The Moringa Tree a Local Solution to Malnutrition? 2005

Wayan Diananto. 5-star tabloid important facts about career women breastfeeding Tuesday, 4 October 2016 03:00:56 WIB

BANK World, 2006, "Repositioning Nutrition as Center for Development").

Joni M.S, Sitorus M, and Katharina N. 2008. Prevent Malnutrition with Moringa. Yogyakarta. Canisius Publisher

Winarti Sri. 2010. Functional Food. Yogyakarta: Graha Science

Zakaria, et al., .2012. Addition of Moringa Leaf Flour to Daily Food Menus in Efforts to Overcome Malnutrition in Toddlers. Food Nutrition Media 8 (1) 
Dachana, K.B, et al. 2010. Effect of Dried Moringa (Moringa Oleifera Lam) Leaves On Rheology, Microstructural, Nutritional, Textural And Organoleptic Characteristics Of Cookies.

Kristina, N.N and Syahid, S.F, Balitro. 2014 Utilization of Moringa (moringa oleifera) plants to increase breast milk production. News of research and development of industrial plant food. Vol. 20 number 3, December 2014

Speroff L, Fritz MA. Clinical Gynecologic Endocrinology and. Infertility. 8th ed Philadelphia, PA USA: Lippincot williams \& Wilkin. 2011

Vyas 2012. Risk of Breast Cancer due to Hyperprolactinemia caused by Antipsychotics (Neuroleptics). British Journal of Medical Practitioners, December 2012, Volume 5, Number 4

UNICEF (United Nations Children's Fund) (1990) Strategy for Improved Nutrition of Children and Women in Developing Countries. Policy Review paper E / ICEF / 1990 / 1.6, UNICEF: New York

Zakaria, Veni Hadju, Suryani As'ad, and Burhanuddin Bahar. 2016. Effect of Extract Moringa Oleifera on Quantity and Quality of Breastmilk in Lactating Mothers, Infants 0-6 Month. URNAL MKMI, Vol. 12 No. 3, September 2016

Simbolon, Jonni Marjuang, Sitorus M., and Katharina Nelly. 2008. Prevent Malnutrition with Moringa. Yogyakarta: Canisius 